\title{
Effect of wheat bran and dried carrot pomace addition on quality characteristics of chicken sausage
}

\author{
Sanjay Yadav ${ }^{1}$, Ashok K. Pathera ${ }^{1, *}$, Rayees UI Islam ${ }^{1}$, Ashok K. Malik ${ }^{1}$, and Diwakar P. Sharma ${ }^{1}$
}

* Corresponding Author: Ashok K. Pathera Tel: +91-99-91-121920, Fax: +91-1662-284312,

E-mail: apathera@gmail.com

' Department of Livestock Products Technology, Lala Lajpat Rai University of Veterinary and Animal

Sciences, Hisar, Haryana 125004, India

ORCID

Sanjay Yadav

https://orcid.org/0000-0002-3569-6963

Ashok K. Pathera

https://orcid.org/0000-0002-1008-5963

Rayees UI Islam

https://orcid.org/0000-0002-4252-3630

Ashok K. Malik

https://orcid.org/0000-0002-2609-6552

Diwakar P. Sharma

https://orcid.org/0000-0003-1659-6972

Submitted Mar 20, 2017; Revised Jun 27, 2017; Accepted Jul 31, 2017
Objective: Effect of addition of wheat bran (WB) and dried carrot pomace (DCP) on sensory, textural, colour, physico-chemical and nutritional characteristics of chicken sausage were evaluated.

Methods: WB and DCP were used as a source of dietary fibre at 3\%, 6\%, and 9\% level individually. Different quality attributes of sausages were estimated. One product from each source with very good sensory acceptability was selected to analyze dietary fibre content and shelf life under refrigerated storage.

Results: Sensory acceptability of 3\% fibre enriched sausage was comparable with control and a further increase in fibre level resulted in a decrease in sensory acceptability. Fibre enriched sausages were significantly harder and less cohesive than control sausage. Significant increase in gumminess and chewiness was observed at $6 \%$ level in WB treated sausages and $9 \%$ level in DCP treated sausages. Moisture content decreased significantly in all treated sausages, protein content decreased significantly in DCP-2 and DCP-3 sausages while fat content decreased in all WB and DCP-3 treated sausages in comparison to control. The fibre enriched sausage had significantly higher dietary fibre and lower cholesterol content. Cooking yield and emulsion stability increased in treated sausages and a significant difference was noticed at $6 \%$ level in both types of sausages. $\mathrm{pH}$ of WB treated sausages was significantly higher and DCP treated sausage significantly lower in comparison to control.

Conclusion: The results of present study indicate that fibre enriched chicken sausage with moderate acceptability can be developed by incorporating WB and DCP each up to $9 \%$ level. Chicken sausage with very good acceptability, higher dietary fibre content and storability up to 15 days at refrigerated temperature can be developed by incorporating WB and DCP at $6 \%$ level each.

Keywords: Chicken Sausage; Wheat Bran; Dried Carrot Pomace; Dietary Fibre; Refrigerated Storage

\section{INTRODUCTION}

Diet is one of the crucial factors influencing health and well-being of the people. During recent years, consumers have changed their liking towards diet and health. Now consumers are more aware of calories, fat and cholesterol and desire a broad variety of nutritious and convenient food products. This inclination has fetched the idea of functional foods in which the main emphasis is on recognizing the potentialities of foods as a promoter of physical and mental health and diminishing the threat of chronic disorders [1]. Meat is specifically valuable as a source of omega-3 fatty acids, vitamin $\mathrm{B}_{12}$, protein and highly bioavailable iron [2] However, meat and meat products are considered harmful for health due to their high saturated fatty acid and cholesterol content. Moreover, meat and its products intrinsically lack dietary fibre which is not favourable for a healthy diet.

Meat products can be made healthy by incorporating dietary fibres from plant sources. 
Dietary fibre has received positive attention in recent years due to its potential to act as pharma food, to reduce cholesterol, diabetes and coronary heart disease as well as to ease constipation [3]. Besides health benefits, fibre can also be used to provide desirable functional properties in meat products. As the fibre has both soluble and insoluble properties, it has a variety of technological characteristics like water binding, gelling and structure building. It can also be used as a fat replacer. Dietary fibre supplementation increases the bulk and prevents cooking loss in meat products which have an economic benefit for both the consumers and processors [4]. Dietary fibres from soy, pea, oat, wheat and sugar beet have been used for development of fibre enriched meat products like patties, sausages and bologna $[5,6]$. Chicken sausage is an emulsion based meat product. Meat emulsion is a two phase system in which fat is dispersed in water. Proteins present in meat acts as emulsifying agents. There has been a dramatic increase in the consumption of chicken sausage throughout the world [7].

Carrot pomace is rich in insoluble fibre rich fraction and comprises of pectic polysac $\neg$ charides, hemicellulose and cellulose [8]. A significant amount of nutritionally important compounds such as carotenes, uronic acids and neutral sugars are also retained in the pomace [9]. Moreover, carrot pomace has the highest percentage of soluble fibre when compared with apple, cabbage, strawberry, black currant and chokeberry pomace. Unlike fruits which may contain kernels and seeds, the pomace received from carrots can easily be added to a product without introducing negative functional or flavour issue while still retaining a lot of its phytochemicals $[10,11]$. Dehydration of pomace results in an increase in fibre content as moisture is lost by drying. Therefore, this by-product can be used as an ideal ingredient for addition into food.

Wheat, rye, rice and most other grains are mainly composed of insoluble fibre [12]. Wheat bran (WB) is the best-known source of insoluble dietary fibre (IDF). Previously called as roughage, this kind of fibre helps to prevent and control bowel diseases and reduces the threat of cancer [13]. Very fewer studies have been reported on the utilization of $\mathrm{WB}$ and dried carrot pomace (DCP) for the development of meat products. Keeping above points in view, this study was conducted to develop fibre enriched chicken sausages using WB and DCP and study the effect of fibre incorporation on quality attributes of fresh and refrigerated stored chicken sausages.

\section{MATERIALS AND METHODS}

\section{Processing of dietary fibre sources}

The WB was procured from local market. Carrots were also procured from local market. They were washed with clean water and subjected to juice extraction. Pomace obtained was washed gently with clean water, squeezed in a muslin cloth to remove excess water and dried at a temperature of $58^{\circ} \mathrm{C} \pm 2^{\circ} \mathrm{C}$ in a hot air drier to obtain dried pomace. Both the fibre sources were ground in an electrical grinder separately, packed in an airtight container and stored in the deep freezer $\left(-18^{\circ} \mathrm{C}\right)$ for further experiment.

\section{Processing of broiler chicken}

Broiler birds of the same age ( 6 to 7 weeks) reared under similar feeding and managemental conditions were slaughtered and dressed as per the standard procedure in the slaughter house of the department. Carcasses were washed thoroughly and breast and leg cuts were separated. Both the cuts were deboned manually after trimming of visible fat and connective tissue. Deboned meat from both the cuts was mixed in equal proportion and frozen for $24 \mathrm{~h}$ in a freezer $\left(-18^{\circ} \mathrm{C}\right)$.

\section{Preparation of chicken sausage}

Deboned and frozen meat obtained from breast and leg cuts was minced in an electrical mincer ( $4 \mathrm{~mm}$ plate). For preparation of control sausage, sodium chloride (1.6 g), sodium tripolyphosphate $(0.3 \mathrm{~g})$, sodium nitrite $(0.015 \mathrm{~g})$, spice mix $(1.9 \mathrm{~g})$, condiments paste $(3 \mathrm{~g})$, refined wheat flour $(2 \mathrm{~g})$, water $(8 \mathrm{~g})$, and groundnut oil ( $4 \mathrm{~g})$ were added to minced meat $(79.2 \mathrm{~g})$. Treatments consisted of the addition of WB and DCP each at three different levels viz. 3\%, 6\%, and $9 \%$ by replacing lean meat. Other ingredients were used in similar concentration as in control. Minced meat along with additives and dietary fibre sources was mixed in a bowl chopper for 4 to 6 min to prepare a stable emulsion. The emulsion was stuffed in artificial cellulose casings (C-25×70 ft., Euromate Food Tech Pvt. Ltd, Noida, India) by hand-operated sausage filling machine and cooked in boiling water in a closed container for 30 minutes. After cooking, sausages were delinked, cooled to room temperature, packaged in low-density polythene bags and stored at refrigerated temperature for further study.

\section{Sensory analysis}

Sensory evaluation was carried by a semi-trained panel consisting of faculty members and research fellows of the department. The panelists were experienced and well informed with different sensory attributes during their post graduate program. They were briefly explained about nature of experiment without revealing the identity of samples. Sausage samples of $2 \mathrm{~cm}$ diameter and $2 \mathrm{~cm}$ thickness were cut, warmed and served to the panel members. Coded samples were presented to test panelists individually and they were asked to evaluate the samples for sensory attributes viz colour and appearance, flavour, texture, tenderness, juiciness and overall acceptability (OAA) using 8-point descriptive scale (where 8 indicates extremely desirable and 1 indicates extremely undesirable). The tests were carried out two hours before or after the midday meal. Drinking water at room temperature was provided to rinse the mouth between sample testing. 


\section{Proximate analysis}

Moisture, protein, fat, ash and crude fibre content of chicken sausage were determined as per the standard procedure of AOAC [14]. Moisture content was determined by using hot air oven and fat content by soxhlet method using petroleum ether (boiling range $60^{\circ} \mathrm{C}$ to $80^{\circ} \mathrm{C}$ ) as a solvent. The Kjeldahl method of digestion, distillation and titration was followed for estimation of protein content. Ash content of samples was determined in a muffle furnace. Crude fibre content was estimated after acid-alkali digestion. Total dietary fibre (TDF), IDF, and soluble dietary fibre (SDF) were determined by the standard procedure of AOAC [15]. The cholesterol content was estimated by the spectrophotometric method by Zak [16] and expressed as $\mathrm{mg} / 100 \mathrm{~g}$ of product.

\section{Physico-chemical analysis}

The cooking yield of the final product was calculated by recording the weight of cooked product and initial raw weight. The $\mathrm{pH}$ of samples was determined as per the method of Trout et al [17] using digital pH meter (CyberScan pH 510, Thermo Fisher Scientific Inc., Waltham, MA, USA). The method of Baliga and Madaiah [18] was used to determine the stability of control and treated emulsions. Thiobarbituric acid reacting substances (TBARS) (mg malondehyde/kg) were determined by the following method of Witte et al [19].

\section{Instrumental texture analysis}

The texture profile analysis was performed as per the procedure outlined by Bourne [20]. Samples of $20 \mathrm{~mm}$ diameter and $15 \mathrm{~mm}$ height were compressed to $50 \%$ of their original height. A time of $5 \mathrm{~s}$ was allowed to elapse between the two compression cycles. Force time deformation curves were obtained with a $50 \mathrm{~kg}$ load cell applied at a cross-head speed of $2 \mathrm{~mm} / \mathrm{s}$. Textural attributes such as hardness, springiness, cohesiveness, gumminess and chewiness were analysed.
For estimation of shear press value, samples $(20 \mathrm{~mm}$ diameter, $15 \mathrm{~mm}$ height) were sheared through Warner Bratzler shear probe of texture analyser.

\section{Instrumental colour analysis}

Colour of all the products was measured using a Konica Minolta chroma meter CR-400 (Konica Minolta Sensing, Inc., Osaka, Japan) with $8 \mathrm{~mm}$ aperture for measurement. The instrument was calibrated with a white standard plate. Colour scores were expressed as International Commission on Illumination Lab L* (lightness), $\mathrm{a}^{*}$ (redness), and $\mathrm{b}^{\star}$ (yellowness).

\section{Refrigerated storage}

Sausages were packaged in low density polyethylene bags and stored at a refrigeration temperature of $4^{\circ} \mathrm{C} \pm 1^{\circ} \mathrm{C}$. The samples were drawn at a regular interval of 5 days from day of preparation ( 0 day) to till spoilage of products. Initially, TBARS value and microbiological quality were analyzed to determine the shelf life of products, and then the sensory quality was determined up to the shelf life of nuggets at an interval of 5 days under refrigerated storage.

\section{Microbiological analysis}

Standard plate count (SPC) (log cfu/g), psychrotrophic count (PC) (log cfu/g), and yeast and mould counts (log cfu/g) were determined by using the method recommended by APHA [21].

\section{Statistical analysis}

The data obtained from six replicates were subjected to analysis of variance. For fresh products, one way analysis of variance (treatment being independent variable) and for refrigerated stored products, two way analysis of variance (treatment and storage period being independent variables) was conducted. Duncan's multiple range test at 5\% significance level was applied to find out significant differences in mean [22].

Table 1. Sensory scores of chicken sausages incorporated with different levels of wheat bran and dried carrot pomace

\begin{tabular}{|c|c|c|c|c|c|c|}
\hline Treatment & Colour and appearance & Flavour & Texture & Juiciness & Tenderness & OAA \\
\hline \multicolumn{7}{|c|}{ Chicken sausages incorporated with wheat bran } \\
\hline Control & $7.29 \pm 0.72^{\mathrm{a}}$ & $7.54 \pm 0.50^{\mathrm{a}}$ & $7.58 \pm 0.51^{\mathrm{a}}$ & $7.75 \pm 0.34^{\mathrm{a}}$ & $7.75 \pm 0.45^{\mathrm{a}}$ & $7.58 \pm 0.51^{\mathrm{a}}$ \\
\hline WB-1 $1^{1)}$ & $7.04 \pm 0.62^{\mathrm{a}}$ & $7.46 \pm 0.45^{\mathrm{a}}$ & $7.46 \pm 0.45^{\mathrm{a}}$ & $7.46 \pm 0.45^{\mathrm{a}}$ & $7.67 \pm 0.39^{\mathrm{a}}$ & $7.46 \pm 0.45^{\mathrm{a}}$ \\
\hline WB-2 & $7.04 \pm 0.50^{\mathrm{a}}$ & $7.12 \pm 0.53^{\mathrm{a}}$ & $7.00 \pm 0.37^{b}$ & $6.96 \pm 0.26^{b}$ & $7.12 \pm 0.23^{b}$ & $7.04 \pm 0.33^{b}$ \\
\hline WB-3 & $6.92 \pm 0.63^{\mathrm{a}}$ & $6.62 \pm 0.71^{b}$ & $6.58 \pm 0.36^{c}$ & $6.62 \pm 0.43^{c}$ & $6.54 \pm 0.45^{c}$ & $6.42 \pm 0.42^{c}$ \\
\hline \multicolumn{7}{|c|}{ Chicken sausages incorporated with dried carrot pomace } \\
\hline Control & $7.38 \pm 0.43^{\mathrm{a}}$ & $7.67 \pm 0.39^{\mathrm{a}}$ & $7.58 \pm 0.51^{\mathrm{a}}$ & $7.83 \pm 0.25^{\mathrm{a}}$ & $7.71 \pm 0.45^{\mathrm{a}}$ & $7.58 \pm 0.51^{\mathrm{a}}$ \\
\hline$D\left(P-1^{2)}\right.$ & $7.00 \pm 0.37^{\mathrm{a}}$ & $7.50 \pm 0.30^{a}$ & $7.58 \pm 0.36^{\mathrm{a}}$ & $7.79 \pm 0.26^{\mathrm{a}}$ & $7.75 \pm 0.26^{a}$ & $7.58 \pm 0.36^{\mathrm{a}}$ \\
\hline DCP-2 & $6.88 \pm 0.38^{\mathrm{a}}$ & $7.04 \pm 0.69^{b}$ & $7.041 \pm 0.58^{b}$ & $7.201 \pm 0.50^{b}$ & $7.04 \pm 0.33^{b}$ & $7.12 \pm 0.38^{\mathrm{a}}$ \\
\hline DCP-3 & $6.88 \pm 0.91^{a}$ & $6.54 \pm 0.69^{c}$ & $6.88 \pm 0.83^{b}$ & $6.79 \pm 0.78^{c}$ & $6.71 \pm 0.66^{b}$ & $6.62 \pm 0.83^{b}$ \\
\hline
\end{tabular}

$\mathrm{n}=12$, mean \pm standard deviation.

OAA, sensory overall acceptability; WB, wheat bran; $D C P$, dried carrot pomace.

1) WB-1, WB-2, WB-3: chicken sausages incorporated with 3\%,6\%, and $9 \%$ wheat bran respectively.

2) DCP-1, DCP-2, DCP-3: chicken sausages incorporated with 3\%, 6\%, and 9\% dried carrot pomace respectively.

${ }^{a-c}$ Means with different superscripts within a column for a particular parameter differ significantly $(p \leq 0.05)$. 


\section{RESULTS AND DISCUSSION}

\section{Sensory quality}

Sensory scores of 3\% fibre incorporated sausage were comparable with that of control (Table 1). No significant difference was noticed in colour scores of both WB and DCP added chicken sausage in comparison to control. A significant decline in flavour scores was noticed at 9\% level in WB and 6\% level in DCP incorporated sausages. A significant decline in texture, juiciness and tenderness scores was noticed at $6 \%$ level in both types of treatments. A significant decline in overall acceptability scores was noticed at $6 \%$ level in bran added sausages and at 9\% level in DCP added sausages. Still, the overall acceptability scores for $6 \%$ and $9 \%$ fibre added sausage were around 7 and 6.5 representing very good and moderate to very good acceptability respectively. The addition of dietary fibre influences the sensory properties of meat products depending on the concentration. Dilution of meaty flavour at higher levels of fibre incorporation resulted in a decrease in flavour scores of fibre enriched sausages. The addition of carrot dietary fibre at a level above $3 \%$ resulted in a decrease in sensory acceptability of dry fermented sausage [23]. Mehta et al [24] also reported a decrease in sensory scores of chicken rolls and patties with increasing levels of rice bran and psyllium husk.

\section{Proximate and physico-chemical quality}

The addition of dietary fibre resulted in a significant decline in moisture content of chicken sausages (Table 2). Dietary fibres are recognized for their ability to bind water. The decline in moisture content of treated products in this study was due to the quantitative replacement of meat with dietary fibre sources containing very low moisture (5.09\% to $9.47 \%$ ) in comparison to meat. Characteristics of dietary fibre used may be another reason for decreased moisture content of treated products. As specified by Elleuch et al [25], the affinity of a dietary fibre to bind water depends upon its source, structure and physicochemical properties. Dietary fibre from algae has higher affinity to hold water and cereal derivatives present the lowest affinity. The low moisture content of treated products in the present study might be due to relatively less water binding ability of fibre sources used. Incorporation of dietary fibre in the dried form has been reported to decrease the moisture content of meat products. The addition of dried raw orange albedo at $2 \%$ level to bologna sausage resulted in a decrease in moisture content [26]. The decrease in moisture content has also been reported in low fat meat balls containing rye bran [13] and Turkish meat balls containing cereal brans (wheat, rye, oat, corn) [27]. The addition of DCP to chicken sausages resulted in a significant decrease in their protein content in comparison to control. Lower protein content in DCP treated sausage was due to less protein content in DCP in comparison to meat. The fat content of chicken sausages decreased after fibre incorporation. All WB treated sausage had significantly lower fat content in comparison to control whereas a significant decrease in fat content was noticed at 9\% level in DCP treated sausages. Ash content increased after fibre addition and a significant increase in comparison to control was noticed at $6 \%$ level in WB treated sausages and 3\% level in DCP treated sausages. This was due to more ash content in WB and DCP in comparison to meat. These results indicate that composition of fibre sources influence the proximate composition of meat products in which they are incorporated. Increased level of carrot dietary fibre resulted in a decrease in moisture and fat content of dry fermented sausage while no significant difference was noticed in protein and ash content [23]. Talukdar and Sharma [28] had reported that addition of WB resulted

Table 2. Proximate and physico-chemical properties of chicken sausages incorporated with different levels of wheat bran and dried carrot pomace

\begin{tabular}{|c|c|c|c|c|c|c|c|c|}
\hline Treatment & Moisture (\%) & Protein (\%) & Fat $(\%)$ & Ash (\%) & Crude fibre (\%) & Cooking yield $(\%)$ & ES $(\%)$ & $\mathrm{pH}$ \\
\hline \multicolumn{9}{|c|}{ Chicken sausages incorporated with wheat bran } \\
\hline Control & $71.33 \pm 0.31^{\mathrm{a}}$ & $16.02 \pm 1.02^{\mathrm{a}}$ & $7.68 \pm 0.45^{\mathrm{a}}$ & $1.68 \pm 0.16^{c}$ & $0.21 \pm 0.06^{d}$ & $98.03 \pm 0.89^{c}$ & $92.82 \pm 1.07^{b}$ & $6.28 \pm 0.03^{b}$ \\
\hline WB-2 & $68.46 \pm 0.44^{c}$ & $15.56 \pm 0.31^{\mathrm{a}}$ & $6.58 \pm 0.36^{c}$ & $2.03 \pm 0.15^{\mathrm{ab}}$ & $0.94 \pm 0.17^{b}$ & $100.65 \pm 0.99^{b}$ & $96.19 \pm 1.35^{\mathrm{a}}$ & $6.34 \pm 0.04^{\mathrm{a}}$ \\
\hline WB-3 & $66.88 \pm 0.57^{d}$ & $15.27 \pm 0.51^{\mathrm{a}}$ & $6.24 \pm 0.47^{c}$ & $2.17 \pm 0.40^{\mathrm{a}}$ & $1.28 \pm 0.15^{\mathrm{a}}$ & $102.60 \pm 0.92^{a}$ & $97.47 \pm 0.88^{\mathrm{a}}$ & $6.36 \pm 0.03^{\mathrm{a}}$ \\
\hline \multicolumn{9}{|c|}{ Chicken sausages incorporated with dried carrot pomace } \\
\hline DCP-2 & $68.17 \pm 0.34^{c}$ & $14.71 \pm 0.51^{b}$ & $7.00 \pm 0.44^{\mathrm{ab}}$ & $2.11 \pm 0.12^{\mathrm{a}}$ & $1.03 \pm 0.23^{b}$ & $101.10 \pm 0.62^{b}$ & $97.57 \pm 1.41^{\mathrm{a}}$ & $6.08 \pm 0.03^{c}$ \\
\hline DCP-3 & $67.29 \pm 0.27^{d}$ & $14.38 \pm 0.63^{b}$ & $6.72 \pm 0.56^{b}$ & $2.27 \pm 0.16^{\mathrm{a}}$ & $1.35 \pm 0.26^{\mathrm{a}}$ & $104.44 \pm 1.60^{\mathrm{a}}$ & $97.71 \pm 1.13^{\mathrm{a}}$ & $5.96 \pm 0.02^{d}$ \\
\hline \multicolumn{9}{|c|}{$\begin{array}{l}n=6 \text {, mean } \pm \text { standard deviation. } \\
E S \text {, emulsion stability; WB, wheat bran; DCP, dried carrot pomace. } \\
\text { 1) Moisture, protein, fat, ash, and crude fibre content of WB was } 9.47,14.01,3.09,4.77 \text {, and } 11.58 \text { respectively. Co } \\
\text { and } 12.93 \text { respectively. } \\
{ }^{2)} \text { WB-1, WB-2, WB-3: chicken sausages incorporated with } 3 \%, 6 \% \text {, and } 9 \% \text { wheat bran respectively. } \\
{ }^{3)} \text { DCP-1, DCP-2, DCP-3: chicken sausages incorporated with } 3 \%, 6 \% \text {, and } 9 \% \text { dried carrot pomace respectively. } \\
\text { a-d Means with different superscripts within a column for a particular parameter differ significantly ( } \leq \leq 0.05) \text {. }\end{array}$} \\
\hline
\end{tabular}


in a decrease in moisture and protein content and increase in ash content of chicken patties.

Meat does not contain dietary fibre. However, a small amount of crude fibre was noticed in control treatment which was due to fibre contributed by spices and condiments (Table 2). As expected, the crude fibre content of sausages increased significantly after incorporation of fibre sources to meat. This was due to the presence of crude fibre in WB (11.58\%) and DCP (12.93\%).

Cooking yield and emulsion stability increased in treated sausages and a significant difference was noticed at $6 \%$ level of fibre incorporation (Table 2). Retention of water by fibre present in treated sausages resulted in an increase in cooking yield and emulsion stability. The addition of carrot fibre improved water binding capacity of pork sausage [29]. Verma and Banerjee [30] have reported that fibre retains water and decreases cooking losses. Emulsion stability and cooking yield increased on the incorporation of rice bran in meat batters [31] and wheat and oat bran in chicken patties [28].

$\mathrm{pH}$ of chicken sausages increased significantly after WB addition whereas DCP incorporation resulted in a significant decrease in $\mathrm{pH}$ values (Table 2). $\mathrm{pH}$ of the fibre source influences the $\mathrm{pH}$ of meat product. Higher $\mathrm{pH}$ of $\mathrm{WB}$ added sausages was due to higher $\mathrm{pH}$ of WB (6.47) whereas, lower $\mathrm{pH}$ of DCP added sausages was due to acidic $\mathrm{pH}$ of DCP (4.94). Goat meat patties having kinnow rind powder extract had lower $\mathrm{pH}$ (6.02) as compared to control which was due to acidic $\mathrm{pH}$ of extracts [32]. The addition of dried orange fibre at 10,15 , and $20 \mathrm{~g} / \mathrm{kg}$ level in dry cured fermented sausage resulted in a progressive decrease in $\mathrm{pH}$ [33]. Similarly, Verma et al [34] observed decrease in $\mathrm{pH}$ of sheep meat nuggets incorporated with guava powder.

TDF, SDF, and IDF content of treatments WB-2 (6\% WB incorporated chicken sausage) and DCP-2 (6\% DCP incorporated chicken sausage) i.e treatments with very good acceptability was estimated and compared with control. Both the treatments had significantly higher TDF and IDF content in comparison to control (Table 3). Treatment DCP-2 had significantly highest dietary fibre content among all the treatments. These results signify that drying of vegetable pomace results in a concentration of fibre in the pomace. The Higher amount of fibre in the pomace also results in higher amount of fibre in the product in which they are incorporated. Treatment DCP-2 had significantly higher SDF content in comparison to control and WB-2 treatments. Fibre derived from fruits and vegetables have a considerably higher proportion of SDF, whereas cereal fibres contain more insoluble cellulose and hemicelluloses [35]. No significant difference was noticed in SDF content of control and WB-2 treatment. This was due to proportionately very less amount of SDF in WB. Ranhotra et al [36] had reported that WB contains a high amount of IDF. Cholesterol content of fibre incorporated sausages were significantly lower than the
Table 3. Dietary fibre and cholesterol content of wheat bran and dried carrot pomace incorporated chicken sausages

\begin{tabular}{lcccc}
\hline Treatment & TDF (\%) & IDF (\%) & SDF (\%) & $\begin{array}{c}\text { Cholesterol } \\
(\mathbf{m g} / 100 ~ g)\end{array}$ \\
\hline Control & $0.33 \pm 0.10^{\mathrm{c}}$ & $0.19 \pm 0.05^{\mathrm{c}}$ & $0.14 \pm 0.05^{\mathrm{b}}$ & $73.09 \pm 2.57^{\mathrm{a}}$ \\
WB-2 $^{1)}$ & $2.98 \pm 0.33^{\mathrm{b}}$ & $2.76 \pm 0.28^{\mathrm{b}}$ & $0.22 \pm 0.05^{\mathrm{b}}$ & $65.50 \pm 3.28^{\mathrm{b}}$ \\
DCP-2 $^{\mathrm{a}}$ & $3.77 \pm 0.33^{\mathrm{a}}$ & $3.32 \pm 0.26^{\mathrm{a}}$ & $0.45 \pm 0.08^{\mathrm{a}}$ & $65.19 \pm 3.97^{\mathrm{b}}$ \\
\hline
\end{tabular}

$\mathrm{n}=6$, mean \pm standard deviation.

TDF, total dietary fibre; IDF, insoluble dietary fibre; SDF, soluble dietary fibre; WB, wheat bran; DCP, dried carrot pomace.

${ }^{1)}$ WB-2 and DCP-2: chicken sausages incorporated with $6 \%$ wheat bran, $6 \%$ dried carrot pomace.

${ }^{a-c}$ Means with different superscripts in a column differ significantly $(p \leq 0.05)$.

control sausage. This was due to the lower meat content in fibre incorporated sausage than control.

\section{Textural and colour quality}

TPA measurements may define the quality of the finished product and can contribute to the selection of the best functional ingredients [37]. Texture profile analysis of control and treated sausage depicted an increase in hardness of both type of sausage in comparison to control (Table 4). The increase in hardness of treated sausage is consistent with sensory evaluation results in which sensory panelists observed a decrease in texture, tenderness and juiciness scores. Springiness decreased in fibre added sausage and a significant decrease in comparison to control was noticed in DCP treated sausages. A significant decrease in cohesiveness with respect to control was also observed in both types of treated sausage. Significant increase in gumminess and chewiness was observed at $6 \%$ level in WB treated sausage and 9\% level in DCP treated sausage which was due to increase in their hardness. Gumminess and chewiness are secondary parameters of texture profile analysis since gumminess depends on hardness and cohesiveness scores and chewiness depend on gumminess and springiness scores. Force needed to shear sausage samples transversely was expressed as shear force. The significantly higher shear force was observed at $9 \%$ bran level in comparison to control, whereas no significant difference was noticed in shear force value of control and DCP treated sausage. Varied results have been obtained on textural properties of meat products depending on amount and type of fibre. Results of the present study agree with those of Eim et al [23], who reported an increase in hardness of dry fermented sausage with an increase in the percentage of carrot dietary fibre. Saricoban et al [38] also reported that addition of WB to cooked beef patties increased their hardness and gumminess and decreased springiness and cohesiveness without influencing the adhesiveness. Similarly, Huang et al [39] noticed an increase in hardness value in rice bran added pork meatballs. However, Garcia et al [40] had reported that addition of peach, apple and orange fibres resulted in decreased hardness and increased springiness of low fat dry fermented 
Table 4. Instrumental texture and colour properties of chicken sausages incorporated with different levels of wheat bran, dried carrot pomace

\begin{tabular}{|c|c|c|c|c|c|c|c|c|c|}
\hline \multirow{2}{*}{ Treatment } & \multicolumn{6}{|c|}{ Texture properties } & \multicolumn{3}{|c|}{ Colour properties } \\
\hline & Hardness (N) & Springiness & Cohesiveness & $\begin{array}{c}\text { Gumminess } \\
\text { (N) }\end{array}$ & $\begin{array}{c}\text { Chewiness } \\
\text { (N) }\end{array}$ & $\begin{array}{l}\text { Shear press } \\
\text { (N) value }\end{array}$ & $L^{*}$ & $a^{*}$ & $b^{*}$ \\
\hline \multicolumn{10}{|c|}{ Chicken sausages incorporated with wheat bran } \\
\hline Control & $20.68 \pm 1.54^{d}$ & $0.87 \pm 0.01^{\mathrm{a}}$ & $0.59 \pm 0.04^{a}$ & $12.32 \pm 1.56^{b}$ & $10.71 \pm 1.27^{b}$ & $5.21 \pm 1.03^{b}$ & $57.82 \pm 1.18^{a}$ & $6.17 \pm 0.58^{\mathrm{a}}$ & $16.60 \pm 1.25^{b}$ \\
\hline WB-11) & $28.35 \pm 3.79^{c}$ & $0.86 \pm 0.05^{\mathrm{a}}$ & $0.45 \pm 0.04^{b}$ & $12.98 \pm 3.07^{b}$ & $11.24 \pm 3.38^{b}$ & $5.62 \pm 0.85^{b}$ & $58.13 \pm 2.59^{\mathrm{a}}$ & $6.14 \pm 0.72^{\mathrm{a}}$ & $17.07 \pm 1.02^{b}$ \\
\hline WB-2 & $39.72 \pm 2.52^{b}$ & $0.86 \pm 0.02^{\mathrm{a}}$ & $0.43 \pm 0.03^{b}$ & $17.07 \pm 2.02^{\mathrm{a}}$ & $14.63 \pm 1.41^{\mathrm{a}}$ & $5.82 \pm 0.59^{b}$ & $58.11 \pm 2.70^{\mathrm{a}}$ & $6.60 \pm 0.63^{\mathrm{a}}$ & $18.98 \pm 0.58^{\mathrm{a}}$ \\
\hline WB-3 & $44.37 \pm 0.67^{\mathrm{a}}$ & $0.84 \pm 0.02^{\mathrm{a}}$ & $0.42 \pm 0.03^{b}$ & $18.72 \pm 1.43^{\mathrm{a}}$ & $15.74 \pm 1.06^{\mathrm{a}}$ & $9.99 \pm 0.65^{\mathrm{a}}$ & $57.80 \pm 2.17^{a}$ & $6.27 \pm 0.31^{\mathrm{a}}$ & $18.54 \pm 1.10^{\mathrm{a}}$ \\
\hline \multicolumn{10}{|c|}{ Chicken sausages incorporated with dried carrot pomace } \\
\hline Control & $20.68 \pm 1.54^{d}$ & $0.87 \pm 0.01^{\mathrm{a}}$ & $0.59 \pm 0.04^{a}$ & $12.32 \pm 1.56^{b}$ & $10.71 \pm 1.27^{b}$ & $5.21 \pm 1.03^{\mathrm{a}}$ & $57.82 \pm 2.93^{\mathrm{a}}$ & $6.17 \pm 0.50^{\mathrm{a}}$ & $16.60 \pm 1.26^{a}$ \\
\hline$D\left(P-1^{2)}\right.$ & $25.07 \pm 0.79^{c}$ & $0.83 \pm 0.01^{b}$ & $0.49 \pm 0.06^{b}$ & $12.24 \pm 1.82^{b}$ & $10.20 \pm 1.59^{b}$ & $5.01 \pm 0.61^{\mathrm{a}}$ & $59.32 \pm 1.25^{\mathrm{a}}$ & $6.05 \pm 0.31^{\mathrm{a}}$ & $17.31 \pm 0.52^{\mathrm{a}}$ \\
\hline DCP-2 & $28.90 \pm 2.01^{b}$ & $0.79 \pm 0.01^{c}$ & $0.42 \pm 0.01^{c}$ & $12.16 \pm 1.05^{b}$ & $9.59 \pm 0.75^{b}$ & $5.09 \pm 0.59^{\mathrm{a}}$ & $58.55 \pm 2.31^{\mathrm{a}}$ & $6.27 \pm 0.47^{\mathrm{a}}$ & $17.57 \pm 0.51^{\mathrm{a}}$ \\
\hline DCP-3 & $38.30 \pm 1.47^{\mathrm{a}}$ & $0.78 \pm 0.01^{c}$ & $0.42 \pm 0.03^{c}$ & $16.12 \pm 1.37^{a}$ & $12.65 \pm 1.19^{a}$ & $5.39 \pm 0.68^{a}$ & $58.93 \pm 2.05^{\mathrm{a}}$ & $6.35 \pm 0.67^{\mathrm{a}}$ & $17.18 \pm 0.50^{a}$ \\
\hline
\end{tabular}

$\mathrm{n}=12$, mean \pm standard deviation.

WB, wheat bran; DCP, dried carrot pomace.

1) WB-1, WB-2, WB-3: chicken sausages incorporated with 3\%,6\%, and $9 \%$ wheat bran respectively.

2) DCP-1, DCP-2, DCP-3: chicken sausages incorporated with $3 \%, 6 \%$, and $9 \%$ dried carrot pomace respectively.

${ }^{a-d}$ Means with different superscripts within a column for a particular parameter differ significantly $(p \leq 0.05)$.

sausages. Insoluble fibre can increase the consistency of meat products by forming an insoluble three dimensional network [41] which can influence the rheological properties of the continuous phase of emulsions. Grossi et al [42] reported that incorporation of carrot dietary fibre in a comminuted meat emulsion, result in a high order of network organization leading to a harder texture and high water binding capacity. Mansour and Khalil [6] had also reported that incorporation of WB to beef burger resulted in a significant increase in shear press value.

No significant difference was noticed in lightness and redness scores of WB and DCP treated sausages (Table 4). Yellowness increased significantly in WB treated sausages. Fibres may influence the colour of meat products due to their diversified colours and presence of pigments. Yasarlar et al [27] reported an increase in yellowness after incorporation of corn, oat and rye brans which was attributed to the presence of carotenoid pigments.

\section{Quality of sausages under refrigerated storage}

TBARS value: TBARS values of fresh control and treated sausages ranged from 0.51 to $0.60 \mathrm{mg}$ malondehyde $/ \mathrm{kg}$ (Table 5). No significant difference was noticed in TBARS value of fresh control and fibre enriched sausages. Significant increase in TBARS value of control and fibre enriched sausage was found with an increase in storage period. However, the increase in TBARS value was comparatively less in treatment DCP-2 resulting in significantly lower TBARS value in DCP-2 treatment on the 20th day of storage. Less increase in TBARS value in above treatment might be due to the presence of bioactive compounds in carrot pomace which exerted an antioxidant effect. Results agree with those of Mehta et al [43] in psyllium husk incorporated chicken patties during refrigerated storage. Aleson-Carbonell et al [44] reported that non fermented dry cured sausages formulated with lemon albedo had lower TBARS values than control samples at the end of storage. The results indicate that DCP was effective in controlling the lipid oxidation in chicken sausages during refrigerated storage.

Microbiological quality: No significant difference was noticed in SPC, PC, and Y \& M counts between control and treated sausages on 0 day as well as during storage (Table 5). The results indicate that fibre addition did not affect the microbiological quality of chicken sausage. SPC, PC, and Y \& M counts increased significantly during storage in both control and treated sausage. Mehta et al [43] also observed similar results in their study on psyllium husk incorporated chicken patties. All the microbial counts were within acceptability limits up to 15th day of storage as prescribed by Jay [45]. SPC crossed acceptability limit on the 20th day of storage as the values were above $10^{6} \mathrm{cfu} / \mathrm{g}$ [46].

Sensory quality: A perusal of Table 6 shows the scores of sensory attributes i.e. colour, flavour, texture, tenderness, juiciness and overall acceptability of fresh and refrigerated stored control and treated sausages. No significant difference in colour scores was noticed between control and treated sausages on 0 day as well as during storage. The scores of control and treated sausages decreased significantly on the 15th day of storage. But the scores were well within the acceptable limits. The decrease in colour during storage might be due to changes in meat pigment myoglobin. Flavour and texture scores of fibre enriched sausages were significantly lower than control sausage on 0 day. Flavour and texture scores of both types of sausage decreased significantly during storage. Deteriorative changes due to lipid oxidation, free fatty acid release and increased 
Table 5. TBARS value (mg malondehyde/kg) and microbiological quality of wheat bran, dried carrot pomace incorporated chicken sausages stored at $4^{\circ} \mathrm{C} \pm 1^{\circ} \mathrm{C}$

\begin{tabular}{|c|c|c|c|c|c|}
\hline Treatment & 0 day & 5th day & 10th day & 15th day & 20th day \\
\hline \multicolumn{6}{|c|}{ TBARS value (mg malondehyde/kg) } \\
\hline Control & $0.57 \pm 0.22^{\mathrm{aE}}$ & $0.82 \pm 0.17^{\mathrm{aD}}$ & $1.29 \pm 0.14^{\mathrm{ac}}$ & $1.68 \pm 0.29^{\mathrm{aB}}$ & $2.16 \pm 0.13^{\mathrm{aA}}$ \\
\hline DCP-2 & $0.51 \pm 0.15^{\mathrm{aE}}$ & $0.79 \pm 0.23^{\mathrm{aD}}$ & $1.10 \pm 0.25^{\mathrm{ac}}$ & $1.50 \pm 0.21^{\mathrm{aB}}$ & $1.92 \pm 0.16^{\mathrm{bA}}$ \\
\hline \multicolumn{6}{|c|}{ Standard plate count (log cfu/g) } \\
\hline Control & $2.65 \pm 0.33^{\mathrm{E}}$ & $3.34 \pm 0.35^{D}$ & $4.24 \pm 0.30^{c}$ & $5.21 \pm 0.40^{B}$ & $6.22 \pm 0.42^{A}$ \\
\hline \multicolumn{6}{|c|}{ Psychrotrophic count (log cfu/g) } \\
\hline Control & $1.47 \pm 0.42^{D}$ & $1.96 \pm 0.32^{c}$ & $2.67 \pm 0.26^{B}$ & $3.06 \pm 0.39^{B}$ & $3.78 \pm 0.42^{\mathrm{A}}$ \\
\hline WB-2 & $1.40 \pm 0.31^{D}$ & $1.81 \pm 0.42^{D}$ & $2.60 \pm 0.43^{c}$ & $3.10 \pm 0.26^{B}$ & $3.74 \pm 0.38^{A}$ \\
\hline DCP-2 & $1.60 \pm 0.33^{D}$ & $1.92 \pm 0.37^{D}$ & $2.46 \pm 0.38^{C}$ & $2.94 \pm 0.29^{B}$ & $3.59 \pm 0.43^{\mathrm{A}}$ \\
\hline \multicolumn{6}{|c|}{ Yeast and moulds count (log cfu/g) } \\
\hline
\end{tabular}

$n=6$, mean \pm standard deviation.

TBARS, thiobarbituric acid reacting substances; WB, wheat bran; DCP, dried carrot pomace.

1) WB-2 and DCP-2: chicken sausages incorporated with $6 \%$ wheat bran, $6 \%$ dried carrot pomace.

${ }^{a-b}$ Means with different superscripts in a column differ significantly $(p \leq 0.05)$.

${ }^{A-E}$ Means with different superscripts in a row differ significantly $(p \leq 0.05)$.

Table 6. Sensory scores of wheat bran and dried carrot pomace incorporated chicken sausages stored at $4^{\circ} \mathrm{C} \pm 1^{\circ} \mathrm{C}$

\begin{tabular}{|c|c|c|c|c|}
\hline Treatment & 0 day & 5th day & 10th day & 15th day \\
\hline \multicolumn{5}{|c|}{ Colour and appearance } \\
\hline Control & $7.42 \pm 0.47^{\mathrm{A}}$ & $7.29 \pm 0.45^{A}$ & $7.04 \pm 0.40^{A B}$ & $6.88 \pm 0.57^{B}$ \\
\hline WB-2 ${ }^{11}$ & $7.21 \pm 0.40^{A}$ & $7.17 \pm 0.39^{A}$ & $6.92 \pm 0.36^{\mathrm{AB}}$ & $6.71 \pm 0.50^{B}$ \\
\hline DCP-2 & $7.13 \pm 0.43^{A}$ & $7.00 \pm 0.30^{A B}$ & $6.75 \pm 0.40^{B}$ & $6.67 \pm 0.49^{B}$ \\
\hline \multicolumn{5}{|l|}{ Flavour } \\
\hline Control & $7.67 \pm 0.49^{\mathrm{aA}}$ & $7.63 \pm 0.48^{\mathrm{aA}}$ & $7.17 \pm 0.72^{\mathrm{aAB}}$ & $6.75 \pm 0.75^{\mathrm{aB}}$ \\
\hline \multicolumn{5}{|l|}{ Texture } \\
\hline Control & $7.58 \pm 0.51^{\mathrm{aA}}$ & $7.54 \pm 0.50^{\mathrm{aA}}$ & $7.08 \pm 0.79^{\mathrm{aAB}}$ & $6.79 \pm 0.62^{\mathrm{aB}}$ \\
\hline WB-2 & $7.08 \pm 0.29^{\mathrm{bA}}$ & $7.00 \pm 0.37^{\mathrm{bAB}}$ & $6.71 \pm 0.45^{\mathrm{aBC}}$ & $6.54 \pm 0.50^{\mathrm{ac}}$ \\
\hline DCP-2 & $7.08 \pm 0.19^{\mathrm{bA}}$ & $7.04 \pm 0.26^{\mathrm{bA}}$ & $6.67 \pm 0.49^{\mathrm{aB}}$ & $6.50 \pm 0.48^{\mathrm{aB}}$ \\
\hline \multicolumn{5}{|l|}{ Juiciness } \\
\hline \multicolumn{5}{|l|}{ Tenderness } \\
\hline Control & $7.67 \pm 0.49^{\mathrm{aA}}$ & $7.50 \pm 0.52^{\mathrm{aA}}$ & $7.25 \pm 0.45^{\mathrm{aA}}$ & $6.83 \pm 0.49^{\mathrm{aB}}$ \\
\hline WB-2 & $7.04 \pm 0.26^{\mathrm{bA}}$ & $6.83 \pm 0.49^{\mathrm{bAB}}$ & $6.63 \pm 0.48^{\mathrm{bBC}}$ & $6.33 \pm 0.49^{b c}$ \\
\hline DCP-2 & $7.00 \pm 0.30^{\mathrm{bA}}$ & $7.00 \pm 0.48^{\mathrm{bA}}$ & $6.71 \pm 0.45^{\mathrm{bA}}$ & $6.25 \pm 0.40^{\mathrm{bB}}$ \\
\hline \multicolumn{5}{|c|}{ Overall acceptability } \\
\hline Control & $7.63 \pm 0.38^{\mathrm{aA}}$ & $7.50 \pm 0.43^{\mathrm{aAB}}$ & $7.17 \pm 0.54^{\mathrm{aBC}}$ & $6.83 \pm 0.54^{\mathrm{ac}}$ \\
\hline WB-2 & $7.08 \pm 0.29^{\mathrm{bA}}$ & $7.00 \pm 0.30^{\mathrm{bA}}$ & $6.67 \pm 0.44^{\mathrm{bB}}$ & $6.38 \pm 0.38^{\mathrm{bB}}$ \\
\hline DCP-2 & $7.00 \pm 0.30^{\mathrm{bA}}$ & $6.96 \pm 0.40^{\mathrm{bA}}$ & $6.71 \pm 0.40^{\mathrm{bA}}$ & $6.33 \pm 0.44^{\mathrm{bB}}$ \\
\hline
\end{tabular}

$n=12$, mean \pm standard deviation.

$W B$, wheat bran; DCP, dried carrot pomace.

${ }^{1)}$ WB-2, DCP-2: chicken sausages incorporated with $6 \%$ wheat bran and $6 \%$ dried carrot pomace respectively.

a,b Means with different superscripts in a column differ significantly $(p \leq 0.05)$

${ }^{A-C}$ Means with different superscripts in a row differ significantly $(p \leq 0.05)$. 
microbial load might have resulted in a decrease in flavour score of sausages during storage. However, at the end of the storage period of 15 days, no significant difference was noticed in flavour and texture scores of control and fibre enriched sausages indicating that decrease in scores for these sensory attributes was less in fibre enriched sausages in comparison to control sausages. Less decline in flavour scores of treated sausage might be due to less deteriorative changes in these treatments due to lesser fat content and presence of bioactive compounds in bran and carrot pomace.

Juiciness, tenderness and overall acceptability scores of treated sausages were significantly lower than control sausage on 0 day as well as during storage. The scores of both types of sausages for these sensory attributes decreased significantly during storage. However, the scores for all the sensory attributes were more than 6.0 on the 15th day of storage meaning treated sausages were moderately acceptable at the end of the storage period of 15 days. The decrease in texture, tenderness and juiciness scores might be due to loss of moisture and fat from the products during storage. Mehta et al [43] reported the decrease in flavour and juiciness scores of psyllium husk incorporated chicken patties during refrigerated storage. Pathera et al [47] also reported decrease in sensory scores of chicken nuggets at the end of refrigerated storage period.

\section{CONCLUSION}

The results of this study indicate that dietary fibre enriched chicken sausages with higher cooking yield and emulsion stability can be prepared by incorporating WB and DCP each at $3 \%, 6 \%$, and $9 \%$ level. Chicken sausage having very good sensory acceptability and with a shelf life of 15 days under refrigerated temperature can be prepared by incorporating WB and DCP each at $6 \%$ level. Hundred gram serving of chicken sausage containing $6 \% \mathrm{WB}$ and $6 \% \mathrm{DCP}$ meet $1 / 8$ th and $1 / 7$ th of recommended daily allowance for dietary fibre respectively. This approach of dietary fibre enrichment in meat products is helpful towards the manufacturer of healthy meat products.

\section{CONFLICT OF INTEREST}

We certify that there is no conflict of interest with any financial organization regarding the material discussed in the manuscript.

\section{ACKNOWLEDGMENTS}

This work was financially supported by Ministry of Food Processing Industries, New Delhi, India, Project F.No.56/MFPI/ $\mathrm{R} \& \mathrm{D} / 2011$.

\section{REFERENCES}

1. Jimenez-Colmenero F, Carballo J, Cofrades S. Healthier meat and meat products: their role as functional foods. Meat Sci 2001;59:5-13.

2. Bender A. Meat and meat products in human nutrition in developing countries. Food and Nutrition Paper 53, Italy, Rome: Food and Agriculture Organization of the United Nations (FAO); 1992.

3. Telrandhe, UB, Kurmi R, Uplanchiwar V, et al. Nutraceuticals - A phenomenal resource in modern medicine. Int J Univ Pharm Life Sci 2012;2:179-95.

4. Grigelmo-Miguel N, Abadias-Seros M, Martin-Belloso O. Characterization of low fat high-dietary fiber frankfurters. Meat Sci 1999;52:247-56.

5. Backers T, Noll B. Safe plant based ingredients for meat processing: Dietary fibres and lupine protein. Food Mark Technol 2001;15:12-5.

6. Mansour EH, Khalil AH. Characteristics of low fat beef burgers as influenced by various types of wheat fibres. Food Res Int 1997;30:199-205.

7. Jayawardana BC, Liyanage R, Lalantha N, Iddamalgoda $S$, Weththasinghe P. Antioxidant and antimicrobial activity of drumstick (Moringa oleifera) leaves in herbal chicken sausages. LWT - Food Sci Technol 2015;64:1204-8.

8. Chau CF, Chen CH, Lee MH. Comparison of the characteristics, functional properties, and in vitro hypoglycemic effects of various carrot insoluble fiber-rich fractions. LWT - Food Sci Technol 2004;37:155-60.

9. Stoll T, Schieber A, Carle R. Carrot pomace-an underestimated by-product? In: Fannhauser WP, Fenwick GR, Khokhar S, editors. Biologically-active phytochemicals in food. Cambridge, UK: The Royal Society of Chemistry; 2001. pp. 525-7.

10. Chantaro P, Devahastin S, Chiewchan N. Production of antioxidant high dietary fiber powder from carrot peels. LWTFood Sci Technol 2008;41:1987-94.

11. Nawirska A, Uklańska C. Waste products from fruit and vegetable processing as potential sources for food enrichment in dietary fibre. Acta Sci Pol Technol Aliment 2008;7:35-42.

12. Southgate DA, Hudson GJ, Englyst H. The analysis of dietary fibre: the choice for the analyst. J Sci Food Agric 1978;29:97998.

13. Yilmaz I. Effects of rye bran addition on fatty acid composition and quality characteristics of low fat meat balls. Meat Sci 2004;67:245-9.

14. AOAC. Official methods of analysis, 16 th edition, Association of Official Analytical Chemists, Washington, DC, USA: AOAC International; 1995.

15. AOAC. Official methods of analysis, 16th Edition, Volume II, Section 45.4.07, Method 985.29; Washington, DC, USA: AOAC International; 1997.

16.Zak B. Simple rapid microtechnic for serum total cholesterol. 
Am J Clin Pathol 1957;27:583-8.

17. Trout ES, Hunt MC, Johson DE, et al. Characteristics of low fat ground beef containing texture modifying ingredients. J Food Sci 1992;57:19-24.

18. Baliga BR, Madaiah N. Quality of sausage emulsion prepared from mutton. J Food Sci 1970;35:383-5.

19. Witte VC, Krouze GF, Bailey ME. A new extraction method for determining 2-thiobarbituric acid values of pork and beef during storage. J Food Sci 1970;35:582-5.

20.APHA. Recommended methods for microbiological examination of foods. Washington, DC: APHA Press; 1984.

21. Bourne MC. Texture profile analysis. Food Technol 1978;33: $62-6,72$.

22. Snedecor GW, Cochran WG. Statistical methods. Calcutta, India: Oxford and IBH Publishing Co; 1980.

23. Eim VS, Simal S, Rossello C, Femenia A. Effect of addition of carrot dietary fibre on the ripening process of a dry fermented sausage (sobressada). Meat Sci 2008;80:173-82.

24. Mehta N, Ahlawat SS, Sharma DP, Yadav S, Arora D. Sensory attributes of chicken meat rolls and patties incorporated with the combination levels of rice bran and psyllium husk. J Anim Res 2013;3:179-85.

25. Elleuch M, Bedigian D, Roiseux O, et al. Dietary fibre and fibrerich by-products of food processing: Characterisation, technological, functionality and commercial applications: a review. Food Chem 2011;124:411-21.

26.Fernandez-Gines JM, Fernandez-Lopez J, Sayas-Barbera E, Perez-Alvarez JA. Effects of storage conditions on quality characteristics of bologna sausages made with citrus fibre. J Food Sci 2003;68:710-5.

27. Yasarlar EE, Daglioglu O, Yilmaz I. Effect of cereal bran addition on chemical composition, cooking characteristics and sensory properties of Turkish meat balls. Asian J Chem 2007;19:235361.

28. Talukdar S, Sharma DP. Development of dietary fibre rich chicken meat patties using wheat and oat bran. J Food Sci Technol 2010;47:224-9.

29. Moller SM, Grossi A. Christensen M, et al. Water properties and structure of pork sausages as affected by high pressure processing and addition of carrot fibre. Meat Sci 2011;87:38793.

30.Verma AK, Banerjee R. Dietary fibre as functional ingredient in meat products: a noval approach for healthy living - a review. J Food Sci Technol 2010;47:247-57.

31. Choi YS, Jong YJ, Choi JH, et al. Quality characteristics of meat batters containing dietary fibre extracted from rice bran. Korean J Food Sci Anim Resour 2007;27:228-34.

32. Devatkal SK, Narsaiah K, Borah A. Anti-oxidant effects of extracts of kinnow rind, pomegranate rind and seed powders in cooked goat meat patties. Meat Sci 2010;85:155-9.
33. Fernandez-Lopez J, Viuda-Martos M, Sendra E, et al. Orange fibre as potential functional ingredient for dry cured sausages. Eur Food Res Technol 2007;226:1-6.

34. Verma AK, Rajkumar V, Banerjee R, Biswas S, Das AK. Guava (Psidium guajava L.) powder as an antioxidant dietary fibre in sheep meat nuggets, Asian-Australas J Anim Sci 2013;26: 886-95.

35. Herbafood. Herbacel AQ Plus [Internet]. Apple and citrus fibre. Neuenburg, Germany: Herbafood Nahrungsmittel GmbH; [2013 Oct 22]. Available from: http://www.herbafood. de/eaqplus.pdf

36. Ranhotra GS, Gelroth JA, Glaser BK, Reddy PV. Nutritional profile of a fraction from air-classified bran obtained from a hard red wheat. Cereal Chem 1994;71:321-4.

37. Herrero AM, Ordonez JA, de Avila R, et al. Breaking strength of dry fermented sausages and their correlation with texture profile analysis (TPA) and physico-chemical characteristics. Meat Sci 2007;77:331-8.

38. Saricoban C, Yilmaz MT, Karakaya M. Response surface methodology study on the optimization of effects of fat, wheat bran and salt on chemical, textural and sensory properties of patties. Meat Sci 2009;83:610-9.

39. Huang SC, Tsai YF, Chen CM. Effects of wheat fiber, oat fiber, and inulin on sensory and physico-chemical properties of Chinese-style sausages. Asian-Australs J Anim Sci 2011;24: 875-80.

40. Garcia ML, Dominguez R, Garlvez MD, Casas C, Sergas MD. Utilization of cereal and fruit fibres in low-fat dry fermented sausage. Meat Sci 2002;60:227-36.

41. Backers T, Noli B. Dietary fibres meat processing. Int Food Mark Technol 1997;12:4-8.

42. Grossi A, Soltoft-Jensen J, Knudsen JC, Christensen M, Orlien V. Synergistic cooperation of high pressure and carrot dietary fibre on texture and colour of pork sausages. Meat Sci 2011;89: 195-201.

43. Mehta N, Ahlawat SS, Sharma DP, Yadav S, Arora D. Development and quality evaluation of chicken patties incorporated with psyllium husk. Haryana Vet 2013;52:6-11.

44. Aleson-Carbonell L, Fernandez-Lopez J, Sendra E, Sayas Barbera E, Perez Alvarez JA. Quality characteristics of a non fermented dry cured sausage formulated with lemon albedo. J Sci Food Agric 2004;84:2077-84.

45.Jay JM. Modern food microbiology. 4 th ed. New Delhi, India: C.B.S. Publishers and Distributors; 2004.

46. Frazier WC, Westhoff DC. Food microbiology. New Delhi, India: Tata McGraw Hill Publishing Co Ltd; 1978.

47.Pathera AK, Riar CS, Yadav S, Singh PK. Effect of cooking methods on lipid oxidation, microbiological and sensory quality of chicken nuggets under refrigerated storage. Cogent Food Agric 2016;2:1232472. 